Sociology of India's Economic Elites

\title{
From "Outsider" to Insider: The Case of Reliance
}

\section{Surajit Mazumdar}

\section{OpenEdition}

\section{Journals}

Electronic version

URL: http://journals.openedition.org/samaj/4278

DOI: $10.4000 /$ samaj.4278

ISSN: 1960-6060

\section{Publisher}

Association pour la recherche sur l'Asie du Sud (ARAS)

\section{Electronic reference}

Surajit Mazumdar, "From "Outsider" to Insider: The Case of Reliance », South Asia Multidisciplinary Academic Journal [Online], 15 | 2017, Online since 06 March 2017, connection on 01 May 2019. URL : http://journals.openedition.org/samaj/4278; DOI : 10.4000/samaj.4278

This text was automatically generated on 1 May 2019.

\section{(C) $\Theta \Theta \Theta$}

This work is licensed under a Creative Commons Attribution-NonCommercial-NoDerivatives 4.0 International License. 


\title{
From "Outsider" to Insider: The Case of Reliance
}

\author{
Surajit Mazumdar
}

\section{Introduction}

1 A fundamental premise of this paper is that the capitalist or business class in any society is a product of its particular historical development. Its character is, therefore, not only variable across societies but can also change in any one society over the course of its development. Changes in the composition of the class are one of the mechanisms through which such transformations of its character can be effected. This paper makes use of a case study of the pre-liberalization rise of a new business group in order to derive insights about the nature of the contemporary Indian capitalist class. The extent to which this group shed its original character and became more industrial in nature before India's opening up process began in 1991 will also be explored.

India's modern capitalist class was born under the very specific conditions of a colonial economy, emerging from a mercantile background and initially under the shadow of foreign dominance even in the sphere of business (Ray 1994). For nearly a century after it came into being, its development was constrained by the extremely limited growth of a modern factory industry that was made possible by colonial conditions. A domestic market-based process after independence saw industrial development become relatively more rapid and diverse. Yet India never quite made the transition to being an industrialized economy before Indian capitalists came to confront a new competitive context with India's full-scale entry into the Globalization process (Mazumdar 2008). Through this period, big business in India remained primarily family controlled and was usually organized in the specific form of the business group.

While the overall extent of industrialization between independence and the onset of liberalization in 1991 remained limited, it was accompanied by a marked continuity as well as important shifts in the composition of Indian big business (Mazumdar 2011). Notwithstanding the continued dominance of older elements within them, entry into and 
exit from the large business sector as well as a significant reordering of relative positions did take place over that period. These changes contradict the commonly held view that the competitive context created by the regulatory regime of Indian dirigisme was tailormade to perpetuate the reproduction of a traditional Indian business elite since it protected this elite from competition from new entrants. However, the change in the composition does not by itself tell us if there was any fundamental transformation in the nature of the capitalist class.

of the new groups that emerged in the large business sector, the Reliance group was the most important representative. The story of its rise to the top ranks of Indian business groups is a chapter of the period after independence and up to the pre-1991 era of Indian capitalism. Its history was not traceable backwards to any old business firm of the preindependence period. Yet, by 1990 Reliance was already among the largest of Indian private business groups, behind only the Tata and Birla (unified) groups in terms of assets. Understanding the basis for the success of Reliance in the context of rivalry with older established constituents of the capitalist class can thus yield some insights about the nature of the change expressed as that growth.

5 The method used to construct the story of the Reliance phenomenon in this paper involved the mutually interacting processes of assembling detailed evidence derived from a variety of available sources and finding a plausible interpretation of all that evidence. Insights into the structure of business groups, available from major studies undertaken in the 1960s (Hazari 1966; Government of India 1969), the ways of identifying linkages within a group and some of their implications proved to be specifically important for this exercise. Our method may be contrasted with a different approach prevalent in some of the current international literature on business groups in "emerging markets" (Bertrand, Mehta and Mullainathan 2002; and Ghemawat and Khanna 1998; Khanna and Palepu 2000 and 2005; Khanna and Rivkin 2001; Khanna and Yafeh 2007; Leff 1978). Eschewing the task of putting together detailed concrete evidence on such groups, the approach in these studies tends to use anecdotal observations to construct explanatory models and derive hypotheses about the behavior of groups that are then sometimes "tested" against the readily available statistical evidence.

6 It should, however, be emphasized that this study has been based entirely on information and data accessible from publicly available documents (details are given in the bibliography). Extensive use was made of the statutory filings with the Registrar of Companies and annual reports of some of its major companies (including their balance sheets and profit and loss accounts). Records of over a hundred companies were examined in the process. In addition, information was culled from reports of India's Monopolies and Restrictive Trade Practices (MRTP) commission or the Bureau of Industrial costs and Prices and other official reports, as well as some prepared by different industry associations. The academic literature existing on the subject and the available official data sources were used to prepare the background story of the textile and petrochemical industries in India as well as internationally. The Bombay Stock Exchange official Directory also provided a great deal of information on the history of many companies engaged in these industries. Of course, what has been extracted from all these sources can only be presented in summary form in this paper. ${ }^{1}$

7 Confidential insider information or interviews of either those involved in the Reliance group or those who dealt with it in any official capacity could, if available, have of course been used as additional material. Some such information is available in published 
biographical accounts (McDonald 1998; Mohnot 1987; Piramal 1997; Piramal and Herdeck 1984). However, this study does not rely excessively on these sources. Part of the reason for this is simply that independent access to reliable material of this kind-to add to or corroborate what was available in existing accounts-would not have been easy to get. Such material could in any case not have completely substituted for the information gathered from the sources mentioned earlier. This was all the more so since one of the objectives of this study was also to shift attention from a virtually exclusive focus on the innate and highly exceptional abilities of a particular individual and to demystify the Reliance phenomenon by bringing out the combination of historical forces that produced it. Directing the effort towards the also significantly difficult task of putting together what was available in the public domain but scattered across a variety of sources thus seemed to be the better route to take. Reinforcing this choice were two important points. First, the final outcome that it was possible to say a lot based on the evidence compiled. Further, this more reliable evidence was also found to be in contradiction with some impressions that have acquired the status of "facts"-for instance the myth that Reliance was forced to resort to capital issues because it could not get credit from public sector financial institutions. ${ }^{2}$

\section{The Reliance group in 1990}

8 Like other Indian groups, the Reliance stable included a large number of companies (close to 200), though only 10 companies and 5 partnership/proprietorship firms were registered under the then existing MRTP Act as inter-connected undertakings of the group. Most of these companies were primarily investment and trading companies and the group's manufacturing activities were concentrated in a small number of companiesthe bulk of them in the one major public company, namely Reliance Industries, and its two subsidiaries. Moreover, manufacturing was the principal business activity and while the large number of investment and trading companies performed important functions, investment and trading were only nominally their business and not the actual reasons for which they existed. They were interconnected to each other through cross-holdings and common directors. Many of them in turn together held a fifth of the share capital of Reliance Industries and this constituted the major part of the stake through which the Ambani family exercised control over the company (the direct holding by the family being less than one percent). A summary and approximate presentation of the structure of inter-corporate investments within the Reliance Group is shown in Figures $1 \mathrm{~A}$ and $1 \mathrm{~B}$, incorporating 141 companies and based on shareholding information for the period from 1983 to 1990. 
Figure 1A

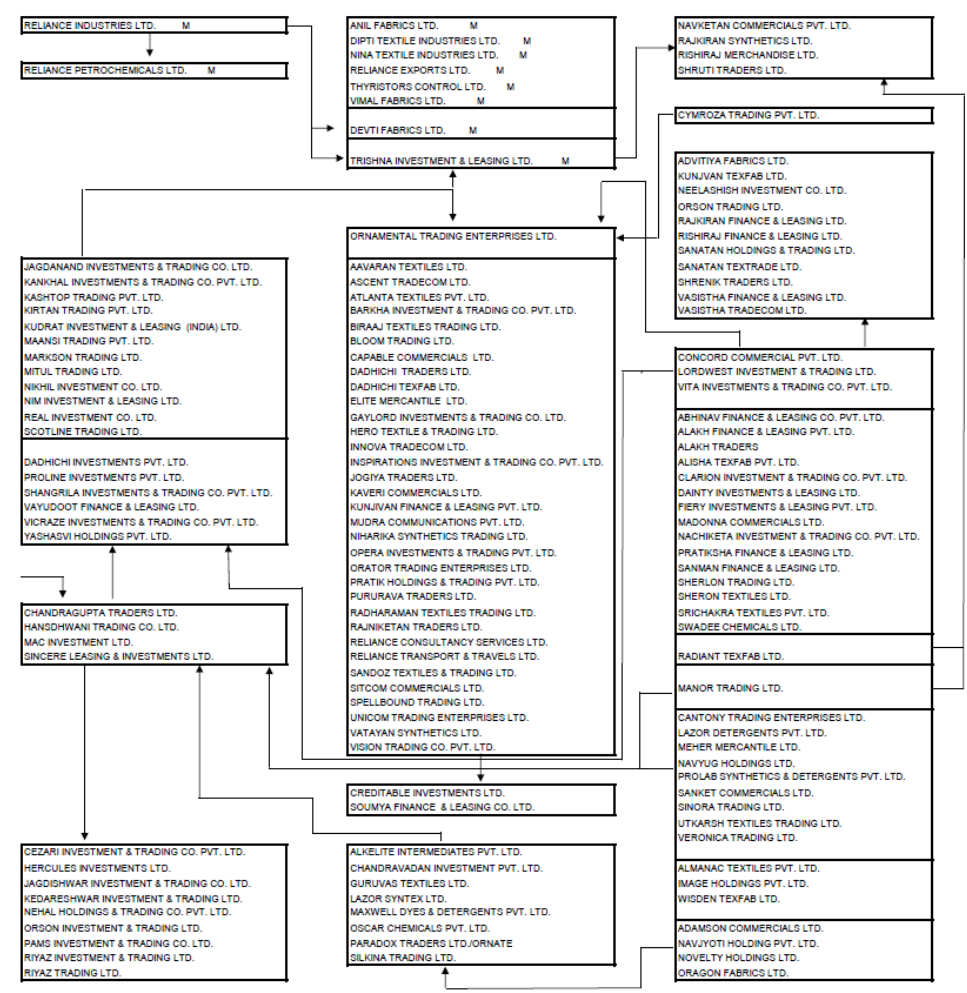

NOTES:

1. COS. MARKED 'M' REgD. UNDER MRTP ACT IN 1990

2. ALL ARROW ORIGINATE FROM COMPANY(IES) HOLDINg THE SHARES

3. ARROW TO/FROM TOP/BOTTOM OF BOX VALID FOR ENTIRE BOX. ARROW TO/FROM SIDE ONLY FOR SUB-BOX 
Figure 1B: Structure of interconnections, Reliance group, Part B

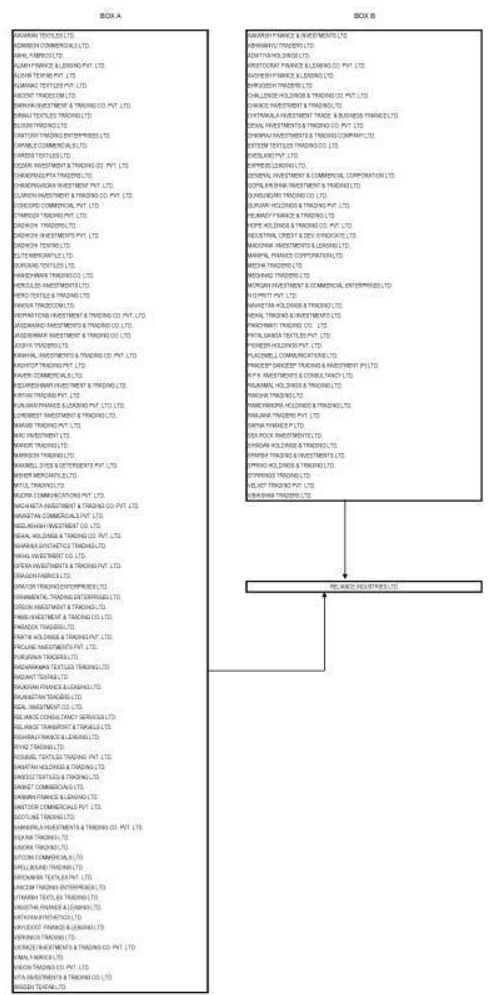

NOTE: COMPANIES IN BOX A APPEAR IN FIg. 1A AS WELL.

While the key figure associated with the rise of Reliance was Dhirubhai Ambani, a larger extended family including not only his two sons but also the immediate families of his brothers, Natvarlal and Ramniklal, as well as their relations by marriage formed a large and cohesive controlling group. While Reliance was not an inherited family business, the Ambani family belonged to a mercantile caste group and their social network had always included wealthy members of their community (McDonald 1998).

In Reliance Industries family members occupied the positions of Chairman, Managing and Joint Managing Directors and Executive Directors in 1990. Another director was T. Ramesh. U. Pai was from the Manipal group with which Reliance had a long association. Two other directors, Jayantilal R. Shah and Mansingh L. Bhakta, had also been directors of the company from the time it was still a private limited company (before 1977). Indeed, the Board of Directors of Reliance Industries in 1990 did not look very different from what it had been nearly a decade and a half before. The Secretary of the company was also the same, as were the auditors and the advocates and solicitors. ${ }^{3}$

11 By the end of the 1980s, Reliance's manufacturing activities were largely concentrated in petrochemicals-with polyester and polyester intermediates forming the core, but with a greater diversification underway. While this gave it a strong linkage with the textile industry, the textiles side proper of Reliance's manufacturing portfolio accounted for less than a fifth of its sales in 1990. It was also in petrochemical products that Reliance had achieved the status of leading firm in a range of industries-accounting for a significant (mostly largest) share in installed capacity, production and sales of Polyester Filament Yarn, Polyester Staple Fiber, Linear Alkyl Benzene, Purified Terepthalic Acid and 
Paraxylene (Tables 1 and 2). Thus it was not only big in an aggregate sense but was also a dominant firm in its industries of operation.

Table 1: Number of Companies and Reliance Share in Installed Capacity in Selected Industries, 1990

\begin{tabular}{|c|c|c|}
\hline Product & $\begin{array}{l}\text { Number } \quad \text { of } \\
\text { Companies }\end{array}$ & $\begin{array}{l}\text { Percentage Share of Reliance in Total Industry Installed } \\
\text { Capacity }\end{array}$ \\
\hline PFY & 16 & $\begin{array}{l}24.41 \\
24.41 \\
24.41\end{array}$ \\
\hline PSF & 10 & $\begin{array}{l}22.95 \\
22.95 \\
22.95\end{array}$ \\
\hline LAB & 3 & $\begin{array}{l}42.86 \\
42.86 \\
42.86\end{array}$ \\
\hline PTA & $1(4)$ & $\begin{array}{l}100.00(42.55) \\
100.00(42.55) \\
100.00(42.55)\end{array}$ \\
\hline Paraxylene & 3 & $\begin{array}{l}74.59 \\
74.59 \\
74.59\end{array}$ \\
\hline
\end{tabular}

FIgURES IN BRACKETS REPRESENT THE POSITION WITH REgARD TO THE AggREgATE OF PTA AND ITS SUBSTITUTE, DMT.

SOURCE: DGTD, HANDBOOK OF INDIgENOUS MANUFACTURERS, 1990; CMIE, MARKETS \& MARKET SHARES, 1991; GOI, BICP (1994).

Table 2: Production Shares and Market Shares of Reliance Industries in 1989-90 (Percentages to Industry Totals)

\begin{tabular}{|l|l|l|l|}
\hline \multirow{2}{*}{ Product } & \multirow{2}{*}{ Reliance Share in Production } & \multicolumn{2}{|l|}{$\begin{array}{l}\text { Reliance } \\
\text { Sales }\end{array}$} \\
\cline { 3 - 4 } & & Share in \\
\cline { 3 - 4 } & & Quantity & Value \\
\hline PFY & 38.04 & 44.32 & 33.61 \\
\hline PSF & 41.93 & 45.53 & 43.78 \\
\hline LAB & 38.54 & 100.00 & 100.00 \\
\hline PTA & $100.00(50.35)$ & \multicolumn{2}{l}{ N.A. } \\
\hline
\end{tabular}




\begin{tabular}{|l|l|l|l|}
\hline Paraxylene & 76.89 & & \\
\hline
\end{tabular}

SOURCE: CMIE, MARKETS \& MARKET SHARES, 1991AND GOI, BICP (1994).

\section{Brief history of the Reliance group}

12 The commercial history of the Reliance group began with the creation of Reliance Commercial Corporation, a partnership firm, in 1958. From then on till 1966, when Reliance Textiles and Engineers Ltd. was registered, the group had apparently no manufacturing activity and was engaged only in trading. Reliance Textiles and Engineers was also the first joint-stock company of the group. This was thereafter always its most important company as well, the entity that eventually became Reliance Industries Ltd. in 1985. ${ }^{4}$ Its growth served as the barometer for the growth of the entire group after 1966. Until 1977 it was a private limited company, which went public in that year.

In terms of its organizational features therefore, three phases of the Reliance group's growth up to 1990 may initially be distinguished: 1958 to 1966, when it operated through partnership or proprietorship firms; 1966 to 1977, when first one and then a few other narrowly-held private limited companies were added to the group's stable; and 1977 to 1990 , the period in which the principal group company became an extremely widely held public limited company, and there was a rapid proliferation in the number of companies in the group.

The incorporation of the first joint-stock company of the group neatly coincides with the entry of the Reliance group into manufacturing. However, the subsequent period up to 1990 can also be divided into two phases on a different basis, with 1982 as a dividing line. Prior to Reliance going public, and for a period subsequent to that, Reliance's principal involvement was in the textile industries. In the 1980s, the focus shifted to polyester and other petrochemicals, and these became the locus of its growth from 1982 onwards and gave rise to the picture in 1990 described above. Thus the period up to 1982 may be called the textiles phase of Reliance's growth and the subsequent period the polyester fibers/ petrochemicals phase. However, it may be noted that the textiles phase after 1977 was not just a mere expansion of past activities, and the same was also true of the polyester/ petrochemicals phase from 1986 . There was also an essential continuity that accompanied each transition and aided it.

\section{8 to 1966: The trading phase}

Reliance Commercial Corporation (RCC) began its business activities with the export of spices and other items to the Middle East and East Africa (Mohnot 1987; Piramal and Herdeck 1984). Somewhere along the line the trading activities were extended to include textiles. By the mid-sixties, Reliance's business involvement with the textile and manmade fibers industry, in particular with what was known as the "art silk" industry, would appear to have been fairly deep. Though the art silk industry in those days was an exportoriented industry, and was given various incentives by the Government for that reason, Reliance's primary focus in this period was not really on exports of rayon textiles but on the domestic market for synthetic fibers. "Exports" were simply the instrument for taking advantage of the incentives and acquiring synthetic fibers whose production had 
not yet taken off in India, though their use in the manufacture of fabrics had acquired proportions of some significance. Thus the early history of the Reliance group coincided with the incipient stages of the development of the synthetic fibers and textiles industry in India.

\section{6 to 1977: The first textile phase}

Subsequent to the coming into being of Reliance Textiles and Engineers, the Reliance group incorporated only 5 other companies before 1977: Reliance Exports (1969), Vimal Fabrics (1973) and three companies in 1975 (Anil Fabrics, Dipti Textile Industries, and Nina Textile Industries). These were to take over the running businesses of three partnership firms in which members of the Ambani family were partners. The growth in the first decade after the entry into manufacturing was, however, quite rapid (Table 3), and by 1975-76 the group had crossed the Rs. 20 crores (200 million) mark in terms of value of assets. At that time, this figure was the asset limit beyond which registration under the MRTP Act was required (even though the actual registration of Reliance companies under the Act occurred in 1978). The combined sales of the group had nearly reached the Rs. 100 crores (1,000 million) mark by 1976-77. Thus, the Reliance Group had reached a fairly large scale even before it included any public company.

Table 3: Selected Balance Sheet Items of Reliance Group Companies, 1970-71 and 1976-77 (Values in Rs. Lakhs)

\begin{tabular}{|l|l|l|l|l|l|l|}
\hline Year & Share Capital & Net Worth & Gross Block & Net Block & Total Assets/Liabilities \\
\hline \multicolumn{5}{|l|}{ RELIANCE TEXTILE INDUSTRIES } \\
\hline $1970-71$ & 65 & 152.18 & 289.14 & 265.03 & 399.81 \\
\hline $1976-77$ & 595.11 & 954.16 & $1,699.92$ & $1,451.45$ & $2,910.87$ \\
\hline TOTAL for All 6 Group Companies & 152.18 & 289.14 & 265.03 & 399.81 \\
\hline $1970-71$ & 65 & $1,023.37$ & $1,756.91$ & $1,489.03$ & $3,082.93$ \\
\hline $1976-77$ & 655.33 & &
\end{tabular}

Source: Company Balance Sheets

As earlier, the core of the group's business activities remained centered around the synthetic textile industry. While Reliance Exports occasionally dabbled in other business, the dominant sector in the group's operations was textiles and ultimately every company within the group focused itself on the textile industry. In 1977, the Reliance group was a combination of an art-silk weaving/knitting unit, a processing house for synthetic fabrics and yarns, and a trader in fabrics and yarn (the indicators in Table 4 serve to establish this). Thus while it had graduated from its purely trading enterprise character in the first phase, it still remained on the intersection between trading and manufacturing. Moreover, while it was an organized sector unit it was actually a part of the "powerloom" sector. $^{5}$ 
Table 4: Indicators of Manufacturing Activity and Capacities of Reliance Group Companies, 1975-76 and 1976-77 (yarn quantities in kilograms and fabric quantities in meters)

\begin{tabular}{|l|l|l|}
\hline & \multicolumn{2}{|l|}{ fotal } \\
Item & \multicolumn{1}{|l|}{ fompanies } \\
\hline & $1975-76$ & $1976-77$ \\
\hline Raw Materials Consumed \\
\hline Yarn & $2,101,253$ & $2,416,260$ \\
\hline Fabrics (Grey) & $8,648,496$ & $6,089,677$ \\
\hline Production & $1,498,450$ & $1,762,983$ \\
\hline Crimped Yarn & $15,273,260$ & $14,391,274$ \\
\hline Fabrics & 246 & 246 \\
\hline Installed Capacity (Numbers/Spindles) \\
\hline Looms & 34 & 34 \\
\hline Knitting Machines & 34 & 2,848 \\
\hline Crimping Machines & 2,848 & 20 \\
\hline Twisting Machines & 20 & \multicolumn{2}{|l}{} \\
\hline
\end{tabular}

\section{Source: Company Annual Reports}

While the group still continued to "export" as a means of securing import entitlements, by the mid-seventies its manufacturing and sales activity was mainly directed towards the domestic market; its export earnings even declined. However, from the entry into manufacturing through the installation of imported machinery up until 1977, the dependence of the group on imports for production and expansion activity was substantial (Table 5).

Table 5: Import Intensity of Reliance Textile Industries Investment and Production, 1975-76 and 1976-77 (Values in Rupees Lakhs)

\begin{tabular}{|c|c|c|}
\hline & $1975-76$ & 1976-77 \\
\hline \multicolumn{3}{|l|}{ 1. Imports } \\
\hline Raw Materials & 420 & 350 \\
\hline Dyes, Chemicals, Stores and Spare parts & 18 & 16 \\
\hline Capital Goods & 84 & 154 \\
\hline
\end{tabular}




\begin{tabular}{|l|l|l|}
\hline Total Imports & 522 & 520 \\
\hline 2. Import Intensity of Investment & \multicolumn{2}{|l|}{} \\
\hline Capital Goods Imports as Percentage of Increase in Plant and Machinery & 28 & 49.68 \\
\hline 3. Import Intensity in Current Costs & \multicolumn{2}{|l|}{} \\
\hline Share of Imports in Consumption of Raw Materials and Dyes, Chemicals, etc. & 41.15 & 48.24 \\
\hline
\end{tabular}

\section{Source: Company Annual Reports}

Much of this expansion of the Reliance group was debt financed (Table 6), and loans accounted for two-thirds of its total liabilities in 1976-77. Public-sector banks and ICICI ${ }^{6}$ were its major creditors. Even the conversion of Reliance Industries into a public company was initially prompted by the condition accompanying the agreement of publicsector financial institutions' to support Reliance's expansion project in 1976-77. All the major public-sector financial institutions ${ }^{7}$ were involved in this arrangement under which they agreed to finance nearly $69 \%$ of the total project cost of Rs. 1,250 lakhs (including foreign currency loans of Rs. 239 lakhs), which was nearly half of the value of the company's assets at that time.

Table 6: Structure of Liabilities of the Reliance Group, 1970-71 to 1976-77

\begin{tabular}{|c|c|c|c|c|}
\hline \multirow{2}{*}{ Year } & \multicolumn{4}{|c|}{ Percentage to Total Liabilities } \\
\hline & Net Worth & Secured Loans & Unsecured loans & Total Liabilities \\
\hline \multicolumn{5}{|c|}{ Reliance Textile Industries } \\
\hline $1970-71$ & 38.06 & 48.10 & 13.84 & 100.00 \\
\hline $1971-72$ & 37.73 & 61.16 & 1.11 & 100.00 \\
\hline $1972-73$ & 33.72 & 65.43 & 0.85 & 100.00 \\
\hline 1973-74 & 35.79 & 63.50 & 0.71 & 100.00 \\
\hline $1974-75$ & 40.63 & 59.24 & 0.06 & 100.00 \\
\hline $1975-76$ & 37.79 & 60.70 & 1.44 & 100.00 \\
\hline $1976-77$ & 32.78 & 65.04 & 2.18 & 100.00 \\
\hline \multicolumn{5}{|c|}{ All Group Companies } \\
\hline $1970-71$ & 38.06 & 48.10 & 13.84 & 100.00 \\
\hline $1971-72$ & 37.73 & 61.16 & 1.11 & 100.00 \\
\hline $1972-73$ & 33.72 & 65.43 & 0.85 & 100.00 \\
\hline
\end{tabular}




\begin{tabular}{|l|l|l|l|l|}
\hline $1973-74$ & 35.78 & 63.46 & 0.76 & 100.00 \\
\hline $1974-75$ & 40.63 & 59.14 & 0.16 & 100.00 \\
\hline $1975-76$ & 38.36 & 62.11 & 1.43 & 100.00 \\
\hline $1976-77$ & 33.19 & 63.84 & 2.20 & 100.00 \\
\hline
\end{tabular}

Source: Company Balance Sheets

Thus it is quite clear that significant support from public-sector financial institutions and banks at an early stage of its history was a critical element in the making of the Reliance story. The establishment of a close association with the Pais of the Manipal group (erstwhile controllers of Syndicate Bank) and with the ICICI would appear to have played an important role in securing this institutional financing. Even before Reliance Textile Industries became a public company, ICICI had become a minority shareholder. There is also clear evidence of the formation of a link with the Pais. During the early 70s (until 1972), Reliance Exports operated a business of rubberized coir products under the agency of Karnataka Coir Products Ltd., a Manipal Group company. As mentioned earlier, the Manipal Group also acquired in this period a minority shareholding in Reliance Textiles, when it was still a private company. So too did Syndicate Bank, with which the Pais had a close association both before and after its nationalization in $1969 .{ }^{8}$ Again, Syndicate Bank gave an irrevocable guarantee in lieu of hypothecation of the plant and machinery for Reliance's borrowing from the ICICI in this period. MAC Investments, an investment company which ultimately was to become (with its eight subsidiaries) a crucial link in the chain connecting various Reliance companies was originally a subsidiary of Maharashtra Apex Corporation, another Manipal Group Company. Mynylon Ltd. referred to in the next paragraph was also associated with the Manipal group. The significance for Reliance's growth in this phase and thereafter of this close personal association with a group that had a long history in financial businesses, and with individuals who were part of the political establishment, cannot of course be calculated from any statistics.

The first manufacturing phase of Reliance's growth came to an end with the public offer for the equity shares of Reliance Textiles in late 1977, and its subsequent listing on the Bombay and Ahmedabad Stock Exchanges in January 1978. The conversion to a public company was, however, accomplished through a complex course. First Reliance Textiles was amalgamated into another company with no business, Mynylon Ltd., whose name in turn was changed to Reliance Textiles and its registered office shifted from Bangalore to Bombay. This otherwise strange sequence was apparently undertaken with the objective of maximizing the increase in the family holding in Reliance Industries before converting it into a public company. The number of shares did increase from 17 to 59.5 lakhs as a result of the amalgamation, and it is from this increase that the family offered 28.2 lakh shares for sale to the public in 1977, in order to get the company listed on the stock exchanges.

\section{7 to 1990: From textiles to petrochemicals}

The first public offer of shares by Reliance Textiles, and the subscription to it, did not bring any additional finance into the company because it only amounted to a change of 
ownership of existing shares. However, the oversubscription of that issue pointed towards possibilities which Reliance was then able to exploit. Recurrent large public capital issues became thereafter a major source of financing for the rapid expansion that made Reliance one of the largest business groups in the country. It became the most significant beneficiary of the capital market boom of the 1980s (Table 7), the conditions for which were created by larger trends in the Indian economy and the consequent increase in financial savings. Public-sector financial institutions continued to provide fairly significant financing support. However, given the scale of expansion, in purely relative terms this support was less significant than it had been before 1977 .

Table 7: Public Capital Issues by the Private Corporate Sector, 1980-81 to 1989-90

\begin{tabular}{|l|l|l|l|l|}
\hline Group & $\begin{array}{l}\text { No. } \\
\text { Issues }\end{array}$ & $\begin{array}{l}\text { Amount } \\
\text { Crores) }\end{array}$ & Raised $\quad$ Rs. & $\begin{array}{l}\text { Percentage to Total Capital } \\
\text { Issues }\end{array}$ \\
\hline \multicolumn{4}{|l|}{ Large Issues (Over Rupees 50 Crores) } & 9.16 \\
\hline Reliance & 8 & $1,749.00$ & 6.61 \\
\hline Tata & 10 & $1,261.76$ & 5.37 \\
\hline Birla & 11 & $1,024.93$ & 5.21 \\
\hline L \& T & 4 & 994.19 & 4.56 \\
\hline Oswal Agro & 4 & 871.72 & 3.74 \\
\hline Usha Rectifier & 3 & 714.50 & 2.65 \\
\hline Essar & 3 & 506.53 & 100 \\
\hline Total Issues & 4,938 & $19,096.54$ & 9.60 \\
\hline Reliance & 13 & $1,833.79$ & \\
\hline Issues) & All & & & \\
\hline
\end{tabular}

Source: Mishra, B. M. (1993)

23 Coinciding with the transformation of Reliance Industries into a public company was the addition of a new dimension to the group's growth-a consistent trend of proliferation of the number of its companies (Table 8). This regular increase in the number of investment and trading companies was associated with the need to increase (even if not proportionately) the shareholding of Reliance Industries that the family could control, even as the share capital base of the company increased massively. Narrowly held investment and trading companies could achieve this objective by subscribing to shares or acquiring them through purchases and financing these purchases by borrowing from institutional and non-institutional sources. The proliferation of companies also made it possible to transfer both the debt and the holdings from one set of companies to another, allowing each of them to service their own individual debt. 
Table 8: Increase in the Number of Companies of the Reliance Group, 1978 to 1989

\begin{tabular}{|l|l|l|l|l|l|l|l|l|l|l|l|l|}
\hline Year-> & $\mathbf{1 9 7 8}$ & $\mathbf{1 9 7 9}$ & $\mathbf{1 9 8 0}$ & $\mathbf{1 9 8 1}$ & $\mathbf{1 9 8 2}$ & $\mathbf{1 9 8 3}$ & $\mathbf{1 9 8 4}$ & $\mathbf{1 9 8 5}$ & $\mathbf{1 9 8 6}$ & $\mathbf{1 9 8 7}$ & $\mathbf{1 9 8 8}$ & $\mathbf{1 9 8 9}$ \\
\hline $\begin{array}{l}\text { Companies } \\
\text { Registered in the } \\
\text { Year }\end{array}$ & 6 & 7 & 2 & 10 & 17 & 21 & 31 & 6 & 49 & 5 & 2 & 5 \\
\hline $\begin{array}{l}\text { Cumulative Total } \\
\text { of Group } \\
\text { Companies }\end{array}$ & $\mathbf{1 2}$ & $\mathbf{1 9}$ & $\mathbf{2 1}$ & $\mathbf{3 1}$ & $\mathbf{4 8}$ & $\mathbf{6 9}$ & $\mathbf{1 0 0}$ & $\mathbf{1 0 6}$ & 155 & $\mathbf{1 6 0}$ & $\mathbf{1 6 2}$ & 167 \\
\hline
\end{tabular}

NOTE: THE ABOVE TABLE EXCLUDES COMPANIES FOR WHOM THE RELEVANT INFORMATION WAS NOT AVAILABLE. 7 COMPANIES THAT WERE REgISTERED EARLIER BUT ACQUIRED DURING THIS PERIOD HAVE ALSO NOT BEEN INCLUDED.

SOURCE: COMPANY MEMORANDUMS OF ASSOCIATION AND DIRECTORY OF JOINT STOCK COMPANIES, 1990

The growth of Reliance Industries however still served as the barometer of the growth of the group (Table 9). In contrast to the earlier phase, the growth of its assets in this period was more rapid than of its sales. This reversal was a result of the gradual replacement by the group of trading and processing related sales by sales based on its own production and its increasing vertical integration. This happened in two stages. The initial expansion after Reliance Industries became a public company was within the textile industry itselfpartly the completion of the expansion project mentioned earlier, which saw an increase in the number of installed looms. The group also entered into the spinning of yarn for the first time when it set up a new unit for the manufacture of man-made fiber yarn on the worsted system. The weaving and spinning capacities were also expanded by the acquisition of a sick industrial unit, Sidhpur Mills (originally belonging to the Shri Ambica group). However, even as Reliance Industries became through these a more conventional textile mill, it also ceased to grow on that basis.

Table 9: Growth of Reliance Industries: 1977-78 to 1989-90 (Values in Rupees Crores)

\begin{tabular}{|l|l|l|l|l|l|}
\hline Year & Share Capital & Net Worth & Net Fixed Assets & Total Assets/Liabilities & Sales \\
\hline $1977-78(15)$ & 6.25 & 14.44 & 25.03 & 57.98 & 120.11 \\
\hline 1979 & 7.84 & 23.63 & 37.74 & 85.42 & 155.13 \\
\hline 1980 & 12.36 & 31.79 & 57.95 & 124.66 & 214.58 \\
\hline 1981 & 16.97 & 57.09 & 105.56 & 222.51 & 312.22 \\
\hline 1982 & 24.40 & 91.54 & 314.61 & 317.98 & 421.03 \\
\hline 1983 & 41.95 & 129.88 & 321.46 & 388.42 & 520.35 \\
\hline 1984 & 51.98 & 246.39 & 426.28 & 490.45 & 622.01 \\
\hline 1985 & 57.41 & 311.12 & 606.80 & 946.76 & 733.14 \\
\hline
\end{tabular}




\begin{tabular}{|l|l|l|l|l|l|}
\hline 1986 & 57.41 & 311.53 & 949.46 & $1,137.34$ & 905.48 \\
\hline $1987-88(18)$ & 157.90 & $1,022.12$ & $1,584.08$ & $1,956.69$ & $1,770.74$ \\
\hline $1988-89(9)$ & 157.91 & $1,071.31$ & $1,502.78$ & $2,123.65$ & $1,112.45$ \\
\hline $1989-90$ & 157.92 & $1,086.98$ & $1,469.01$ & $2,203.31$ & $1,840.66$ \\
\hline
\end{tabular}

NOTE: FIgURES IN PARENTHESES INDICATE NUMBER OF MONTHS IN THE RELEVANT ACCOUNTINg PERIOD WHEN DIFFERENT FROM A YEAR SOURCE: COMPANY ANNUAL REPORTS

The Reliance group's textile manufacturing capacities, measured in terms of spindlage and loomage, remained virtually frozen from 1979 onwards and the increase in capacity thereafter was limited to that due to modernization operations (Table 10). The entire thrust of expansion shifted towards petrochemicals, which was in fact initiated alongside the last major expansion in textiles. The commissioning of the Polyester Filament Yarn (PFY) project in 1982 marked the first realized step of this change in course. By the mid 1980s, Reliance had applied for and secured clearances (partial or complete) for expanding its PFY capacity and setting up large capacities for the manufacture of a range of petrochemicals-Polyester Staple Fibre (PSF), Purified Terepthalic Acid (PTA), Monoethylene Glycol (MEG), Linear Alkyl Benzene (LAB), High Density Polyethylene (HDPE), Polyvinyl Chloride (PVC), and Synthetic Filament Yarn including Industrial Yarn/ Tyre Cord. By the end of the 1980s, it had secured further Letters of Intent or Licenses for the manufacture of Ethylene, Propylene, and Butadiene, Synthetic Rubber, as well as acrylic fiber. In other words, its planned areas of expansion covered the entire range of the four main categories of petrochemicals-viz. plastics, synthetic fibers, synthetic rubber, as well as the synthetic organic chemicals used in their manufacture. In this period the group also secured clearances for a few projects outside the sphere of petrochemicals-for the manufacture of colored glass shells and TV tubes as well as Chlorine (with Caustic Soda and Hydrogen as by-products).

Table 10: Installed Capacity of Reliance Group Companies, 1977-78 to 1989-90

\begin{tabular}{|c|c|c|c|c|c|c|c|c|}
\hline & \multicolumn{4}{|l|}{ TEXTILES } & \multicolumn{4}{|c|}{ PETROCHEMICALS } \\
\hline Product $\rightarrow$ & \multicolumn{2}{|c|}{$\begin{array}{l}\text { Cotton/Blended/ } \\
\text { Crimped Yarn }\end{array}$} & \multicolumn{2}{|c|}{ MMF Fabrics } & PFY & PSF & PTA & LAB \\
\hline Unit $\rightarrow$ & $\begin{array}{l}\text { Spindles/ } \\
\text { Nos. }\end{array}$ & $\begin{array}{l}\text { Crimping and } \\
\text { Twisting } \\
\text { Machines/ } \\
\text { Nos. }\end{array}$ & $\begin{array}{l}\text { Looms/ } \\
\text { Nos. }\end{array}$ & $\begin{array}{l}\text { Knitting } \\
\text { Machines/ } \\
\text { Nos. }\end{array}$ & M.T. & M.T. & M.T. & M.T. \\
\hline End-Year & RELIANCE & NDUSTRIES & & & & & & \\
\hline $1977-78$ & 0 & 61 & 450 & 22 & 0 & 0 & 0 & 0 \\
\hline 1979 & 9,582 & 80 & 450 & 22 & 0 & 0 & 0 & 0 \\
\hline
\end{tabular}




\begin{tabular}{|c|c|c|c|c|c|c|c|c|c|}
\hline 1980 & 12,494 & 122 & & 450 & 22 & 0 & 0 & 0 & 0 \\
\hline 1981 & 50,682 & 130 & & 940 & 22 & 0 & 0 & 0 & 0 \\
\hline 1982 & 50,682 & 200 & & 940 & 22 & 10,000 & 0 & 0 & 0 \\
\hline 1983 & 50,682 & 221 & & 940 & 22 & 10,000 & 0 & 0 & 0 \\
\hline 1984 & 50,682 & 0 & & 940 & 22 & 10,000 & 0 & 0 & 0 \\
\hline 1985 & 12,494 & 0 & & 450 & 18 & 25,125 & 45,000 & 0 & 0 \\
\hline 1986 & 12,494 & 0 & & 450 & 16 & 25,125 & 45,000 & 0 & 0 \\
\hline 1987-88 & 12,494 & 0 & & 450 & 20 & 25,125 & 45,000 & 100,000 & 60,000 \\
\hline $1988-89$ & 12,494 & 0 & & 450 & 20 & 25,125 & 45,000 & 100,000 & 60,000 \\
\hline $1989-90$ & 12,494 & 0 & & 450 & 20 & 25,125 & 45,000 & 100,000 & 60,000 \\
\hline & \multicolumn{9}{|c|}{ DEVTI FABRICS } \\
\hline 1986 & 36,448 & & 0 & 490 & 0 & 0 & 0 & 0 & 0 \\
\hline 1987 & 35,496 & & 0 & 490 & 0 & 0 & 0 & 0 & 0 \\
\hline $1988-89$ & 36,546 & & 0 & 490 & 0 & 0 & 0 & 0 & 0 \\
\hline $1989-90$ & 37,536 & & 0 & 490 & 0 & 0 & 0 & 0 & 0 \\
\hline
\end{tabular}

Source: Company Annual Reports

Of course not all of these approvals had been converted into actual capacities by 1990. In 1985, the capacity of the PFY plant was increased by 2.5 times and a horizontal diversification was achieved with the commissioning of the PSF plant. In 1987-88, the PTA and $\mathrm{LAB}$ capacities were commissioned, the former representing a backward integration from PFY and PSF manufacture. A further step in backward integration was achieved in 1989 with the commencement of paraxylene production for the manufacture of PTA. The MEG, HEG, HDPE, PVC, Chlorine and by-products projects were still under implementation in 1990 while those of others had not been initiated.

The strategy of growth that Reliance pursued in the 1980s was thus clearly not that of the backward integration of a synthetic textile manufacturer. On the contrary, the expansion strategy adopted was one of using its base in the synthetic textile industry to transform itself into an enterprise with the manufacture of petrochemicals as its core activity. Facilitating that metamorphosis was the essential link between its earlier base in textiles and its new thrust in petrochemicals provided by synthetic yarns. As in the earlier phase, in the petrochemical phase as well the growth of Reliance was based on the domestic market but required an exceptional ability to command imports and foreign exchange. Large capital goods and technology imports were associated with its major foray into petrochemical manufacture in the 1980s. Further, its backward 
integration process only involved the replacement of one set of its imports by another, so the imported component of its raw material consumption remained high throughout (Table 11).

Table 11: Import Intensity of Current Consumption of Reliance Industries, 1977-78 to 1989-90 (Percentage Share of Imports)

\begin{tabular}{|l|l|l|}
\hline Raw material Consumption & Dyes, Chemicals, Spares and Parts Consumed & Total \\
\hline 56.77 & 37.00 & 54.67 \\
\hline
\end{tabular}

Source: Company Annual Reports

\section{Explaining Reliance's growth} transitions from trading to processing and manufacturing activities, and from textiles to petrochemicals, the trajectory of the Reliance group remained firmly tied to that of the synthetic textiles industry in India. Even the growth in the 1980s, though mainly outside the textile industry proper, was based on products that were part of the chain of production of synthetic textiles. In other words synthetic textiles provided a common thread to a process of growth that took place along the intersections of the textile and chemical industries, where the shifting weight was one of the features of Indian industrialization over the period. The path of rapid expansion that Reliance took advantage of was created by the overall trajectory of import-substituting industrialization based on a dissemination of technology from advanced capitalism. industry, which had until then been an extremely slow-changing industry (Kroese 1971 and 1972; Strolz 1971; Thiriez 1970). Technological changes originating in the textile machinery and chemical industries, the conditions of the Golden Age, and the new political context of the world, were the driving forces of these changes. The increasing use of synthetics as opposed to natural (and even rayon) fibers-polyester being the most important-and the increasing speed of machinery and use of newer techniques like knitting were indications of the changes in textile manufacture that were initially most marked in the advanced economies. Alongside that, however, was also a redistribution of the more conventional spinning-weaving and cotton based textile production towards the underdeveloped economies. Synthetic fibers and their intermediates were products of the petrochemical industry, and a handful of advanced-country MNCs came to initially dominate world synthetic fiber production (Read 1986; Spitz 1988; Tisdell and MacDonald 1979). The end of the Golden Age in the 1970s and the consequent crisis of the synthetic fiber industry, along with the ongoing process of global redistribution of textile production, set the stage for a more widespread diffusion of synthetic fiber manufacture to the Asian continent and a process of import-substitution in them.

31

India too was incorporated into the changes within the global textile and synthetic fiber industries but in its own specific way (Alam 1982; Chandrasekhar 1984; Chaudhuri 1994; Goswami 1990; Khanna 1984, 1989; Mishra 1993; Siddharthan and Narayanan 1990). The initial redistribution of world textile production did not have any significant impact in 
India. It was one of the few Third World countries that already had substantial textile industry and the Indian process of import-substitution in textiles had been completed before independence. Instead, stagnant demand conditions in India and an increasing shift of fabric production into the "decentralized sector" resulted in a protracted crisis for the organized textile industry-most acutely in its fabric production segment. However, there was a gradual penetration of synthetic fibers and a trend of change in the fiber composition of textiles. This penetration first took the form of imports and then synthetic fiber manufacture and the petrochemical industry got established in the 1960s at the state's initiative and with its support.

Though the growth of synthetic fiber and fiber intermediate production was in itself of an import-substituting kind, the growth of the synthetic textiles and fibers industry had at the same time a domestic production-replacing character. In comparison to the cotton textiles that they replaced, synthetic textile growth had to be significantly more importdependent for both inputs as well as technology. Foreign exchange availability and the import-policy environment therefore were important factors conditioning their growth. The greatest expansion and rapid import-substitution in these industries actually took place in the 1980s, so that India also came to participate in the global redistribution of such manufacturing.

33 Notwithstanding the crisis in the organized textile industry, organized sector units did play an important role in the increasing penetration of synthetic fibers. To begin with, before the 1980s, most of the processing of yarn as well as the production of synthetic fabrics were undertaken by organized units-some of the traditional spinning-weaving mills focused on blended fabrics, while organized units outside the mill sector in the artsilk industry specialized in synthetic fabrics. At this time, synthetic fibers were costly and the market for synthetic textiles was small and concentrated in the upper-income segments. In the 1980s, however, the global cheapening of synthetic fibers relative to cotton, partly through the increased scales of production of these fibers in India, led to a greater penetration of synthetics into the mass-market for textiles. The more conventional "decentralized" or powerloom units, however, led this process. Yet this meant an expansion of the market for synthetic fibers and the scope for growth in their manufacture-behind the wall of protection from imports-and the production of synthetic fibers and intermediates was the natural preserve of organized sector units. In comparison to the other textile related activity, technological factors made the minimum levels of concentration in their production also significantly higher.

Clearly Reliance's trajectory of growth was one that closely reflected the overall pattern of expansion for organized units connected to the textile industry, associated with the increasing penetration of synthetic fibers. The group began with trading in synthetic fibers. It then moved into the manufacturing and processing of synthetic textiles and the processing of synthetic yarns, enabling the group to grow through its participation in the process of substitution of cotton textiles by synthetic textiles in the upper segment of the market. Since Reliance had no history in that industry, it was able to avoid the parallel crisis that afflicted the cotton textiles industry. In the 1980s, as the scope for growth of organized sector units in synthetic textile manufacture tended to reach a plateau, Reliance moved backwards and tied its fortunes with the synthetic fiber and petrochemical industries, where the potential growth opportunities for individual organized sector enterprises came to be greater. The base in these industries in turn 
enabled the horizontal expansion into the manufacture of other petrochemicals that Reliance initiated towards the end of the decade.

What is in addition a remarkable feature of Reliance's growth is that even in the Indian context it was not a pioneering firm-whether one considers the activities with which the Reliance group began its manufacturing history or any one of those it subsequently diversified into. It was typically a later entrant in all of them, though usually before they had achieved full maturity. Synthetic textile manufacturing, including both knitting and weaving units, existed before 1966 and Reliance as a trading enterprise in fact did business with them. The spinning of synthetic fiber yarn began much before Reliance entered into that field in the late 1970s. Reliance's entry into PFY manufacture was nearly a decade and a half after its first production in India, while the same gap in the case of PSF was two decades. The public sector Indian Petrochemicals Corporation (IPCL) initiated the manufacture of polyester intermediates in 1973, again a decade and a half before Reliance's entry into this activity. Even in the case of LAB, Reliance followed IPCL and the private sector Tamil Nadu Petroproducts of the M. A. Chidambaram group.

Not only was it typically a later entrant, Reliance's entry in most of the industries was also as part of a generalized trend of investment in them in which other new entrants or incumbent firms, both private and public sector, also participated. In other words, the directions in which it chose to seek growth opportunities were not typically unique.

In its textiles phase, the Orkay group closely resembled the Reliance group. The Orkay group, like Reliance, was not a traditional large group, and began its business activities through partnership firms. Orkay Silk Mills, the principal group company in 1990, was incorporated in 1968 to take over the business of a partnership firm set up in 1957. The group was involved in the organized synthetic textiles industry till the 1980s, like Reliance combining the knitting and weaving of textiles with the processing of fabrics and synthetic yarns. In the 1980s, it too diversified, like Reliance and in the same year, into the manufacture of PFY as part of a proposed expansion into chemicals. ${ }^{9}$

In 1981, apart from Reliance and Orkay, two of the existing manufacturers of PFY, Petrofils Co-operative and J. K. Synthetics, were also granted approval for substantial increases in their capacity. Between that year and 1984, before Reliance secured approval for its entry into PSF manufacture, two existing units, J. K. Synthetics and BRPL, and two new entrants, India Polyfibres and Orissa Synthetics, secured approvals for a large addition to the industry capacity. Indeed in the 1980s, four-fifths of the capacity expansion in PFY and PSF manufacture was accomplished by some 20 odd firms other than Reliance. Apart from Reliance, J. K. Synthetics, Bombay Dyeing of the Nowrosjee Wadia group, and the public sector Bongaigaon Refinery and Petrochemicals (BRPL) and IPCL expanded or created capacities for polyester-intermediate manufacture. The combining of PSF and PFY manufacture was done before Reliance by J. K. Synthetics, which along with BRPL also preceded Reliance in going in for a degree of vertical integration in polyester manufacture.

If its expansion was nevertheless of an exceptional magnitude it was because of two features of Reliance's growth:

No other group or company operating in the same industries as Reliance managed to achieve involvement in all the industries it was able to diversify into through its sequence of expansion. Orkay for example matched Reliance's trajectory up to the point of entry into polyester manufacture but not thereafter. BRPL, manufacturing paraxylene, 
Dimethyl Terepthalate (DMT), and PSF, came the closest to Reliance's petrochemicalproduct profile, but did not have the same involvement in the textile industry. Neither did IPCL, a producer of paraxylene and DMT, and a host of other petrochemicals in whose production Reliance was still creating its entry capacities in 1990. Other private groups combining involvement in the textile and synthetic fiber industries on the other hand had no presence in fiber intermediate and petrochemical industries, with the exception of the limited captive capacities for DMT and MEG of the J. K. group. Bombay Dyeing produced one fiber intermediate, DMT, but the Nowrosjee Wadia group was not involved in synthetic fiber manufacture.

41 In both its textiles as well petrochemicals phase, the Reliance group managed to secure for itself a larger share in the expansion of its chosen areas as compared to most other participating enterprises. In each venture it undertook, Reliance acquired a dominant position despite being a later entrant. Its large share in 1990 in petrochemical products has already been highlighted. In its earlier phase, Reliance also clearly became one of the dominant enterprises within the organized art-silk industry. The emergence of a dominant firm of the type that Reliance became in either phase was in itself a likely possibility given the inherently concentrated structure of the industries it operated in. In its textiles phase, the limited size of the upper end of the market for synthetic textiles, the prevalence of non-price competition in it, and the restricted access of firms to imported machinery and inputs, gave it an inherently oligopolistic character. In synthetic fiber and petrochemical manufacture, the existence of significant economies of scale made for highly concentrated industries. Indeed, as the Reliance group graduated from the synthetic textiles to fibers and then to the fiber-intermediates industries, it moved in the direction of industries where scale factors were more and more significant. This made the sequence of its diversification something that could not be easily replicated by a number of firms. By achieving it, the Reliance group successively left behind other enterprises competing with it in an earlier stage of its expansion, even as its scales of production and vertical integration reinforced its position vis-à-vis these competitors.

To sum it up then, the story that the Reliance group scripted for itself over its life span from its birth to 1990, a short span of two and a half decades, had its objective basis in factors largely originating outside the group itself, where it had little direct impact or influence. The path that Reliance followed to become one of the largest business groups in India was a creation of the specific pattern of industrialization in the postindependence period. Like other traditionally dominant Indian business groups, it used foreign technology as the basis for taking advantage of that path and was not a technological innovator. Like them it also made significant use of external finance-from both public-sector institutions and the capital market in the 1980s. Even the boom in the capital issues market was something that had its basis in the increased significance of the financial savings of the household sector, which emerged starting in the late 1970s. The investment opportunities the Reliance group used were also not in areas overlooked by other firms or considered too risky by them. At each stage the group was induced to move in particular directions by a combination of its own past history as well as the operation of generalized inducements to which other firms also responded. But in its entire sequence of diversification across phases, and the consequent ultimate combination across industries, in its relative position in each industry and the capital issues market, as well as in the scale of its expansion, Reliance was unique amongst all these enterprises. ${ }^{10}$ 
But here again objective circumstances dictated that the Reliance-type story, at least in terms of its magnitude, had to be a somewhat unique one.

It says something about the nature of Indian capitalism and its capitalist class that such a remarkable story of movement to the top of the corporate hierarchy in India as Reliance's was based on so little of what could be considered as expressions of industrial entrepreneurship. The only two related elements that can be identified as the key to separating Reliance from others-those that made Reliance rather than any of its actual and potential rivals the most successful exploiter of the opportunities that were in principle open to other firms-were its exceptional success in gaining from the regulatory regime and in mobilizing financing.

Reliance's expansion was achieved in the context of rivalry with other firms which played itself out not primarily in the marketplace but in the determining of the preconditions or parameters of market rivalry. The execution of the growth strategy of Reliance and its rivals necessarily involved multiple points of interaction with the prevailing regulatory regime. Every industry Reliance entered into was governed by the industrial licensing policy so that capacity creation had to be "approved." Once it became registered under the MRTP Act, additional approvals were required. Foreign collaboration and imports also required approvals and import licenses. If public-sector institutions were the sources of institutional financing, capital issues were also subject to government approval. The levels of taxes, excise duties and import duties were also crucial in determining profitability and market prospects in the industries Reliance operated in. Of course, Reliance was not subject to any exceptional regulation, nor was it the only firm to try and use the regulatory regime to its advantage. The evidence, however, does indicate that Reliance's success in getting a favorable configuration of decisions by State agencies was rather exceptional through most of its history:

The direct results of favorable decisions on the financing side of Reliance's growth were the support of the public-sector financial institutions and the approvals for making use of the potential for capital issues in the 1980s. It is in the latter that Reliance proved to be somewhat "innovative" and the use of this mode of financing also contributed to reduction in costs of finance. The consequent improvement in profitability in turn also increased the availability of retained earnings for financing expansion. Adding to this was the fact that Reliance paid virtually no taxes on its profits for two decades-taking advantage of available concessions.

While it managed to secure licenses and MRTP approvals for what were then fairly large capacity creations/expansions in the petrochemicals industries, Reliance also benefited from the fact that rivals who might have created barriers to its entry by creating similar capacities or diversified structures before Reliance were denied similar approvals. A perusal of rejections/approvals under the MRTP Act for capacity creation, for example, reveals that the Thapar group's proposal for setting up a PFY plant with a larger capacity than that created by Reliance, and made before Reliance actually began its production, was rejected after two years. By contrast, just a year after, Reliance's proposal for substantially increasing its capacity was approved within the month. Similarly, the Shri Ram group's LAB proposal made before Reliance was also rejected as were those of others subsequently. Not only applications of other groups for large capacities, but also those that could have created other similarly vertically or horizontally integrated petrochemical manufacturers as Reliance were also rejected-for instance, the Thapar group's applications for both PFY and PTA, and of the J. K. Singhania group for PFY, PSF 
and PTA. It had been widely alleged that Reliance succeeded in installing capacities that were much larger than its stated and licensed capacities, and these allegations were even translated into official charges made by the customs authorities (Mohnot 1987). As far as evidence goes, it is true that Reliance Industries' actual production figures for PFY were much higher than its stated installed capacity, almost double in 1989-90. Similarly, in the case of PTA production, in its very first year of operation, Reliance's PTA plant produced $25 \%$ over its stated capacity. Though it was not the only manufacturer with a capacity utilization of over $100 \%$, the gap between its production and the industry average per unit was larger than in other manufacturers' capacities.

Not only was Reliance able to be a major net user of scarce foreign exchange throughout its expansion path, its raw material consumption and technology imports were more foreign-currency intensive than those of its peers. Also, in the 1980s, the raising of customs duties on imports of certain products and the lowering of excise duties on the same, at times coincided with Reliance's switch from importing the product to producing it. Thus, in the case of both PFY and PSF, Reliance's entry was followed by sharp rises in customs duties on imports of these products and in the case of the latter, there was also a parallel reduction in excise duties.

The success that Reliance achieved on the financing side, in combination with that in securing approvals, enabled Reliance to pursue a strategy-encompassing the combination of industries, degree of vertical integration, scales of production and technology choices-different from that of any of its rivals. Apart from allowing the group to achieve a larger size, these also secured a decisive advantage for Reliance when the polyester industry faced difficulties because of overcapacity in the late 1980s and some firms turned sick.

\section{Conclusion}

The phenomenal success of Reliance was very much a product of the pre-1991 regime of Indian capitalism, though the group was also able to make use of that success as the foundation to benefit greatly from the subsequent liberalization process. This of course begs the question-was Reliance truly an outsider which forced its way into the Indian business elite by achieving business success and overcoming the disadvantages of not being initially a part of it? Or was its success itself based on its finding a way to become a privileged insider and making use of the means made available by that privilege? On balance, it would seem that the Reliance story was a specific reflection of the fact that in Indian capitalism business success has heavily relied upon securing means-financing, technology and state support-from the outside rather than on creating technological and managerial capabilities within firms that would be proprietary in nature. Many, though not all, older members of the business elite were able to use precisely this feature to transform their enterprises and grow even as the industrial landscape changed and the industries in which they had originally established themselves declined in importance. Reliance's success and the way it was achieved, however, serves to establish that the degree of influence commanded by a business firm did not have a simple relationship with its past business success, as the causality also operated in the other direction. The growth of Reliance and the survival among the elite of those it joined thus had common roots-highlighting in the process the persistence of the mercantile element in Indian capitalism. Given this, it cannot really be said that the rise of Reliance was an expression 
of a fundamental transformation in the nature of India's capitalist class. That the ability to influence government decisions has been an important facet of Reliance's success even after 1991 (Guhathakurta 2014) would suggest that some essential features of Indian capitalism have survived the transition to liberalization.

\section{BIBLIOGRAPHY}

$\underline{\text { Books, Articles and Reports }}$

Alam, Ghayur. 1982. "Growth of Man-made Fibre Industry in India with Special Reference to Changes in International Technology Market.” New Delhi, ICRIER-NCAER. Mimeograph.

Bertrand, Marianne, Paras Mehta and Sendhil Mullainathan. 2002. "Ferreting Out Tunneling: An Application to Indian Business Groups.” The Quarterly Journal of Economics 117(1): 121-48.

Boon, Gerard K. 1981. Technology Transfer in Fibres, Textile and Apparel. Alphen aan Rijn, The Netherlands: Sijtoff \& Noordhoff.

Chalapati Rao, K. S. 1985. "Inter-connections under the MRTP Act in the Context of Asset Limit Hike." Economic and Political Weekly 20(27): 1,132-46.

Chandrasekhar, C. P. 1984. "Growth and Technical Change in Indian Cotton-Mill Industry." Economic and Political Weekly, Review of Political Economy. 19(4): PE22-PE39.

Chandrasekhar, C. P. 1999. "Firms, Markets and the State: An Analysis of Indian Oligopoly." Pp. 230-66 in Economy and Organization: Indian Institutions under the Neoliberal Regime, edited by A. K. Bagchi. New Delhi: Sage Publications.

Chaudhuri, Saumitra. 1994. Cotton Yarn Spinning in India: The Competitive Advantage and Prospects, ICRA Sector Focus Series \# 1. New Delhi: Investment Information and Credit Rating Agency of India Limited.

Clairmonte, Frederick and John Cavanagh. 1981. The World in Their Web: Dynamics of Textile Multinationals. London: Zed Press.

Dutta, Sudipt. 1998. Family Business in India. New Delhi: Response Books.

Ghemawat, Pankaj and Tarun Khanna. 1998. "The Nature of Diversified Business Groups: A Research Design and Two Case Studies.” The Journal of Industrial Economics 46(1): 35-61.

Goswami, Omkar. 1990. "Sickness and Growth of India's Textile Industry: Analysis and Policy Options." Economic and Political Weekly 25(44): 2,429-39 and 25(45): 2,496-506.

Government of India. 1961. Handbook of Export Promotion. New Delhi: Ministry of Commerce and Industry.

Government of India. 1964. Report of the Powerloom Enquiry Committee. New Delhi: Ministry of Industry.

Government of India. 1969. Report of the Industrial Licensing Policy Inquiry Committee (ILPIC Report), Main Report and Appendices. New Delhi: Department of Industrial Development, Ministry of Industrial Development, Trade and Company Affairs. 
Government of India. 1976. "Petrochemicals in the Public Sector, Extracts from the Performance Budget of the Union Ministry of Petroleum, 1976-77." ICMF (Indian Cotton Mills Federation) Journal 12(11).

Government of India. 1985. Report of the Expert Committee on the Textile Industry. New Delhi: Ministry of Supply and Textiles.

Government of India. 1994. Report on Paraxylene, DMT and PTA. New Delhi: Bureau of Industrial Costs and Prices, Ministry of Industry.

Government of India. 1999. Report on Polyester Filament Yarn. New Delhi: Bureau of Industrial Costs and Prices, Ministry of Industry.

Guhathakurta, Paranjoy. 2014. Gas Wars, Crony Capitalism and the Ambanis. New Delhi: Paranjoy Guhathakurta, AuthorsUpFront and Feel Books

Guillén, Mauro F. 2000. "Business Groups in Emerging Economies: A Resource-based View." The Academy of Management Journal 43(3): 362-80.

Hazari, R. K. 1966. The Structure of the Private Corporate Sector: A Study of Concentration, Ownership and Control. Bombay: Asia Publishing House.

Khanna, Sushil. 1984. "Transnational Corporations and Technology Transfer, Contours of Dependence in Indian Petrochemical Industry." Economic and Political Weekly, Annual Number. 19 (31/33): 1,319-40.

Khanna, Sushil. 1989. "Technical Change and Competitiveness in the Indian Textile Industry." Economic and Political Weekly 24(34): M103-M111.

Khanna, Tarun and Krishna Palepu. 2000. "Is Group Affiliation Profitable in Emerging Markets? An Analysis of Diversified Indian Business Groups.” The Journal of Finance 55(2): 867-91.

Khanna, Tarun and Krishna Palepu. 2005. "The Evolution of Concentrated Ownership in India: Broad Patterns and a History of the Indian Software Industry." Pp. 283-324 in A History of Corporate Governance around the World: Family Business Groups to Professional Managers edited by R. Morck. Chicago: University of Chicago Press.

Khanna, Tarun and Jan W. Rivkin. 2001. "Estimating the Performance Effects of Business Groups in Emerging Markets." Strategic Management Journal 22(1): 45-74.

Khanna, Tarun and Yishay Yafeh. 2007. "Business Groups in Emerging Markets: Paragons or Parasites.” Journal of Economic Literature 45(2): 331-72.

Khurana, Rakesh. 1981. Growth of Large Business, Impact of Monopolies Legislation. New Delhi: Wiley Eastern Limited.

Koedam, Hans E. 1971. “Cotton in Expanding Textile Market.” ICMF (Indian Cotton Mills Federation) Journal 8(2).

Kroese, W. T. 1971 and 1972. "A Quarter-Century of Textile History.” ICMF (Indian Cotton Mills Federation) Journal. 8(7), 8(8), 8(9) and 8(10).

Kumar, L. R. 1986. Sanctioned Capacities for Industries: November 1973 to March 1986. Delhi: Indcom Associates.

Leff, Nathaniel H. 1978. "Industrial Organization and Entrepreneurship in the Developing Countries: The Economic Groups.” Economic Development and Cultural Change 26(4): 661-75.

Mazumdar, Surajit. 2006. "Business Groups and Concentration in the Private Corporate Sector in India." PhD dissertation, Center for Economic Studies and Planning, Jawaharlal Nehru University. 
Mazumdar, Surajit. 2008. "The Corporate Sector and Indian Industrialization: A Historical Perspective." Pp. 193-236 in Industrial Development and Globalisation, edited by S. R. Hashim, K. S. Chalapati Rao, K. V. K. Ranganathan and M. R. Murthy. New Delhi: Academic Foundation.

Mazumdar, Surajit. 2011. "The State, Industrialization and Competition: A Reassessment of India's Leading Business Enterprises under Dirigisme." Economic History of the Developing Regions 26 (2): 33-54.

McDonald, Hamish. 1998. The Polyester Prince: The Rise of Dhirubhai Ambani. Sydney: Allen and Unwin.

Mishra, B. M. 1993. "Developments in the Primary Capital Market During the Eighties and Early Nineties." Reserve Bank of India Staff Studies. Bombay: Department of Economic Analysis and Policy. Mimeograph.

Mishra, Sanjiv. 1993. India's Textile Sector: A Policy Analysis. New Delhi and London: Sage Publications.

Mohnot, S. R. 1987. Reliance: An Industrial Legend. New Delhi: Centre for Industrial \& Economic Research.

Piramal, Gita and Margaret Herdeck. 1984. India's Industrialists. Vol. 1. Washington: Three Continents Press.

Piramal, Gita. 1997. Business Maharajas. New Delhi: Penguin Books India.

Ramaiya, Arunchata. 1992. Guide to the Companies Act. $12^{\text {th }}$ ed., edited by Y. V. Chandrachud, S. M. Dugar, P. M. Narielvala, T. Raghavan and A. P. Datar. Nagpur: Wadhwa and Company.

Ray, Rajat K. 1994. “Introduction.” Pp. 1-69 in Entrepreneurship and Industry in India, 1800-1947, edited by R. K. Ray. Delhi: Oxford University Press.

Read, Robert A. 1986. “The Synthetic Fibre Industry: Innovation, Integration and Market Structure." Pp. 196-224 in Multinationals and World Trade: Vertical Integration and the Division of Labour in World Industries, edited by M. C. Casson and Associates. London: George Allen and Unwin. Royal Dutch/Shell Group of Companies. 1983. The Petroleum Handbook. $6^{\text {th }}$ ed. Amsterdam: Elsevier Science Publishers.

Siddharthan, N. S. and K. Narayanan. 1990. "Synthetic Fibre Industry: Structure, Technology Expenditures, and Performance.” Delhi: Institute of Economic Growth. Mimeograph. Spitz, Peter H. 1988. Petrochemicals: The Rise of an Industry. New York: John Wiley and Sons. Sreenivasan, K. and Indira Doraiswamy. 1973. Survey of the Knitting Industry. Coimbatore: SITRA. Strolz, Herwig. 1971. "Trends in World Textile Industry: Shift in Raw-Material Base and Capacity." ICMF (Indian Cotton Mills Federation) Journal 8(6).

Thiriez, Marcel. 1970. “Structural Changes in European Textile Industry.” ICMF (Indian Cotton Mills Federation) Journal 7(2).

Tisdell, C. A. and P. W. MacDonald. 1979. Economics of Fibre Markets: A Global View of the Interdependence between Man-made Fibres, Wool and Cotton. Oxford, New York, Toronto, Sydney, Paris, Frankfurt: Pergamon Press.

Uchikawa, Shuji. 1998. Indian Textile Industry: State Policy, Liberalization and Growth. New Delhi: Manohar Publishers.

Wingate, Isabel B. 1976. Textile Fabrics and their Selection. Englewood Cliffs, New Jersey: PrenticeHall Inc. 
Winterbottom, W. T. 1966. “Man-made Fibres as a Textile Catalyst.” ICMF (Indian Cotton Mills Federation) Journal. 3(7).

Statistical and Other References

\section{A. Government}

Compendium of Textile Statistics, 1991 and 1993: Office of the Textile Commissioner, Ministry of Textiles, Government of India, Bombay

Consumer Purchases of Textiles, Market Research Wing, Textiles Committee, Ministry of Commerce, Government of India, Bombay

CSO, National Accounts Statistics, various issues: Central Statistical Organisation, Department of Statistics, Ministry of Planning and Programme Implementation, New Delhi.

Directory of Joint Stock Companies in India 1980: Research and Statistics Division, Ministry of Industry, Government of India, New Delhi.

Directory of Joint Stock Companies in India 1985: Research and Statistics Division, Ministry of Industry, Government of India, New Delhi.

Directory of Joint Stock Companies in India 1990: Research and Statistics Division, Department of Company Affairs, Ministry of Law, Justice and Company Affairs, Government of India New Delhi.

Directory of MRTP Companies, 1987 to 1990: Department of Company Affairs, Government of India, published in August issue of Company News and Notes.

Government of India, 1965, 1968, 1977: Directory of Indian Exporters, Directorate General of Commercial Intelligence and Statistics, Calcutta

Government of India, List of Textile Mills as on $31^{\text {st }}$ March 1990: Office of the Textile Commissioner, Ministry of Textiles, Bombay

Handbook of Indigenous Manufacturers (Chemical and Misc. Stores), 1990: Directorate General of Technical Development, Ministry of Industry, Government of India, New Delhi

Indian Textile Bulletin, various years: Office of the Textile Commissioner, Ministry of Commerce, Government of India, Bombay

Reserve Bank of India: Private Corporate Business Sector in India, Selected Financial Statistics from 1950-51 to 1997-98 (All Industries), Company Finances Division, Department of Statistical Analysis and Computer Services, Mumbai

\section{B. Non-Government}

(Bombay) The Stock Exchange Official Directory, various years: Bombay Stock Exchange, Bombay.

ASFI (Association of Synthetic Fibre Industry), various years: Handbook of Statistics on Manmade/Synthetic Fibre/Yarn Industry, Bombay

Chandhok, H. L. and The Policy Group, 1990: India Database: The Economy, Annual Time Series Data, Living Media India, New Delhi

CIER's Industrial Databook, 1994: Centre for Industrial and Economic Research, New Delhi

CMIE (Centre for Monitoring Indian Economy): Market and Market Shares, February 1991, Bombay 
SASMA (Silk and Art Silk Mills Association Ltd.), 1964: Directory of Members (Brought out on Silver Jubilee of Association), Bombay

SASMA (Silk and Art Silk Mills Association Ltd.), 1966: Statistical Supplement for Year 1965-66, Bombay

SASMIRA (Synthetic and Art Silk Mills' Research Association), 1974: Statistics Man-made Textiles, Bombay

\section{International}

UN (United Nations), various years: Industrial Statistics Yearbook/Yearbook of Industrial Statistics, Department of Economic and Social affairs/Statistical Office of the UN

UN (United Nations), 2001 and 2002: Industrial Commodity Statistics Yearbook

\section{Reliance}

Annual Reports of Reliance Industries and Subsidiaries, 1975-76 to 1989-90

Annual Returns, various years, and other filings of 115 Companies submitted to the Registrar of Companies, Bombay and Bangalore.

\section{NOTES}

1. More details are available in Mazumdar (2006)

2. Khanna and Palepu (2005) citing India Unbound: From Independence to the Global Information Age by Gurcharan Das.

3. The founder of one of the auditing firms, D.N. Chaturvedi, was supposed to be part of the inner think-tank of the Reliance group (Mohnot 1987).

4. Incorporated as Reliance Textiles and Engineers Ltd., it was eventually transformed into Reliance Textile Industries Ltd. before finally acquiring the name Reliance Industries Ltd. Technically, however, there was a discontinuity in between which is explained shortly.

5. Organized sector refers to formally registered units/establishments/factories. In the clothproducing textile industry, the major component of the organized sector was classified as the mill sector (spinning and weaving mills) while the "decentralized" sector included handloom units as well as weaving units using power driven looms (mainly unregistered but including some registered units).

6. ICICI is presently a private-sector bank. It was originally however a publicly-sponsored industrial development bank (see 7 below), which-though created in the private sector with shares held by banks, insurance companies, and international financial institutions-effectively became a government company with the nationalization of banks and insurance.

7. The Industrial Development Bank of India (IDBI), the Industrial Finance Corporation of India (IFCI), the Industrial Credit and Investment Corporation of India (ICICI), the Unit Trust of India (UTI), the Life Insurance Corporation of India (LIC) and the General Insurance Corporation (GIC) and its subsidiaries

8. Dattaraj Salgaocar, of the Salgaocar group and son in law of Dhirubhai Ambani, in a tribute to his father-in-law stated that both K.K. Pai (Chairman and Managing Director of Syndicate Bank from 1972 to 1978, and custodian of the Bank after nationalization) and T.A. Pai (Chairman of Syndicate Bank before nationalization, and subsequently a Union Minister) were close common friends of Dhirubhai Ambani and his father in the early 1970s (Goa Today, August 2002).

9. The approvals for the establishment of PFY plants by Reliance and Orkay were on the same date. 
10. This statement needs a small qualification: in terms of the absolute increase in size between 1966 and 1990, the Tata and Birla groups achieved a greater expansion than Reliance.

\section{ABSTRACTS}

At the time of India's liberalization, the Reliance group was already one of India's leading business groups and in subsequent years it has only solidified its place at the top of India's corporate hierarchy. Reliance was not, however, among the "traditional" large groups that emerged during the colonial era and remained dominant in the mid-1960s. This paper traces the story of the Reliance phenomenon and briefly discusses the process (method) by which that story was constructed. In addition to demystifying the phenomenon, the paper seeks to demonstrate there is sufficient evidence available to assert that the basis for the success of Reliance was fundamentally no different from that which other groups used to perpetuate their dominant position, and that the roots of this success lay in the nature of Indian capitalism.

\section{AUTHOR}

\section{SURAJIT MAZUMDAR}

CESP/SSS. Jawaharlal Nehru University 